\title{
Development of enteric coated tablets from spray dried extract of feverfew (Tanacetum parthenium $L$.)
}

\author{
Juliana Siqueira Chaves, Fernando Batista Da Costa, Luís Alexandre Pedro de Freitas*
}

Department of Pharmaceutical Sciences, Faculty of Pharmaceutical Sciences of Ribeirão Preto, University of São Paulo

\begin{abstract}
Tanacetum parthenium (feverfew) is an herb that is commercialized worldwide as a therapeutic treatment for migraine. Its pharmacological effect is mainly due to the presence of the sesquiterpene lactone parthenolide as well as of flavonoids. So far, there are no studies on standardization of pre-formulations or phytomedicines containing this herb. The present study aimed at developing a pre-formulation using a standardized spray-dried extract of feverfew and further designing and standardizing enteric coated tablets. In this work, the spray-dried extract of feverfew was evaluated for its parthenolide, santin and total flavonoid content, parthenolide solubility, particle size, tapped density, hygroscopicity, angle of repose and moisture content. Tablets containing the spray-dried extract were tested for their average weight, friability, hardness, and disintegration time. The total flavonoid and parthenolide contents in the spray-dried extract were $1.31 \%$ and $0.76 \% \mathrm{w} / \mathrm{w}$, respectively. The spray-dried extract presented consistent pharmacotechnical properties and allowed its tableting by direct compression. Tablet properties were in accordance with the proposed specifications. The procedures described herein can be used to prepare and evaluate pre-formulations of feverfew with adequate properties for the development of a high-quality phytomedicine.
\end{abstract}

Uniterms: Enteric coated tablets. Flavonoids. Parthenolide. Phytomedicine. Spray-dried extract. Tanacetum parthenium.

Tanacetum parthenium (tanaceto) é uma planta medicinal comercializada no mundo todo para tratamento de enxaqueca. Seu efeito farmacológico é creditado principalmente à lactona sesquiterpênica partenolídeo e flavonóides. Até o momento não existem estudos sobre a padronização de pré-formulações ou o desenvolvimento de fitoterápicos com tanaceto. Logo, o objetivo deste trabalho foi obter comprimidos de revestimento entérico a partir de extrato seco e padronizado de tanaceto. Neste trabalho, o extrato seco do tanaceto obtido pelo método de spray drying foi avaliado quanto ao teor de partenolídeo, presença da santina, teor de flavonóides totais, solubilidade do partenolídeo, tamanho de partícula, ângulo de repouso, densidade, análise higroscópica e teor de umidade. A partir do extrato seco obtiveram-se comprimidos que foram revestidos em leito de jorro. Os comprimidos revestidos foram avaliados com relação ao peso médio, friabilidade, dureza e desintegração. O teor de flavonóides totais e de partenolídeo no extrato seco foram $1,31 \%$ e $0,76 \%(\mathrm{p} / \mathrm{p})$, respectivamente. O extrato seco apresentou características farmacotécnicas satisfatórias permitindo a obtenção de comprimidos pelo método de compressão direta. As propriedades dos comprimidos revestidos estão de acordo com as especificações da literatura. Os procedimentos utilizados nesse trabalho podem ser utilizados para obter extrato seco e fitoterápicos de T. parthenium com alto padrão de qualidade.

Unitermos: Comprimidos de revestimento entérico. Extrato seco. Fitoterápicos. Flavonóides. Partenolídeo. Tanacetum parthenium.

\footnotetext{
*Correspondence: L. A. P. Freitas. Laboratório de Física Industrial, Departamento de Ciências Farmacêuticas, Faculdade de Ciências Farmacêuticas de Ribeirão Preto, Universidade de São Paulo, Av. do Café, s/n, 14040-903, Ribeirão Preto, SP, Brasil. E-mail: lapdfrei@fcfrp.usp.br
} 


\section{INTRODUCTION}

Herbal medicines have a long history of traditional use and play an important role in the primary health care of developing countries (Calixto, 2000). Nonetheless, in many developed countries, herbal medicinal products - or phytomedicines - are widely used and retail sales surpass billions of dollars (Barnes, 2003). The aerial parts of feverfew [Tanacetum parthenium L. Shultz Bip., Asteraceae] have been used since ancient times for a variety of medicinal purposes because of its anti-inflammatory, analgesic and antipyretic properties. Nowadays it is a recommended therapeutic treatment for migraine prophylaxis (Khan et al., 2003). Although the pathophysiology of migraine is not yet fully understood, its symptoms are reported by $15 \%$ of females and $6 \%$ of males in the adult age, from 35 to 45 years (Pfaffenrath, 2002). Clinical trials have demonstrated the high effectiveness of feverfew against headache and other symptoms linked to migraine (Palevith, 1997). Amongst feverfew constituents are sesquiterpene lactones, flavonoids and spiroketal enol ethers (Bolhmann, Zdero, 1982; Long et al., 1999; Williams et al., 2003). Parthenolide, a sesquiterpene lactone, is the major constituent of the herb and accounts for many of its biological activities. For instance, it has been shown that parthenolide presents in vitro inhibitory effect on the release of serotonin from blood platelets (Vogler, 1998; Weber et al., 1997), in vivo antinociceptive and anti-inflammatory effects and in vitro and in vivo inhibition of several eicosanoids (Hwang et al., 1996; Fukuda, 2000; Kwok et al., 2001). Furthermore, other studies have shown that the feverfew flavonoids also present anti-inflammatory activity (Long et al., 1999; Williams et al., 2003).

Parthenolide is usually employed as a chemical marker in quality control of feverfew products. Due to the importance of this compound, besides the evaluation of its biological activities, many studies describing its quantification by HPLC methods have been published (Zhou et al., 1999; Abourashed, Khan, 2000).

Despite of its importance in the herbal medicine market, several feverfew products are still sold as hard gelatine capsules containing grinded aerial parts of the plant, which substantially increases the difficulties of standardization and quality control as well as the establishment of therapeutic effectiveness of this herbal medicine.

Over the last few years, the industrial manufacture of phytomedicines has grown considerably. For this reason, organizations like the World Health Organization (WHO), the European Union (EU) and the European Scientific
Co-operative on Phytotherapy (ESCOP) have been demanding regulatory guidelines and conclusive studies on chemical, physical and pharmacological properties of herbal drugs for their approval (Barnes, 2003; Silano et al., 2004). Moreover, the market demand for plant medicines is based on reliable products, obtained by validated methods and standardized. One of the most used methods for extracts stabilization and standardization is the spray drying using technological carriers (Senna et al., 1997; Linden et al., 2000).

Dry extracts show a number of advantages over the conventional fluid forms, including higher amounts of active compounds, higher stability, easier standardization and quality control, which therefore increase the therapeutic efficacy and product value (Runha et al., 2001). Furthermore, the design and formulation of herbal medicine tablets is a challenging task due to poor tableting properties of plant extracts (Palma et al., 2002).

Therefore, the aim of the present study was to develop enteric coated tablets of feverfew using its spray dried extracts.

\section{MATERIAL AND METHODS}

\section{Chromatographic standards}

Parthenolide was isolated from Talauma ovata ST. HIL (Magnoliaceae) according to a previously reported method (Stefanello, Alvarenga, 1997).

Santin was isolated from the T. parthenium powder (aerial parts) according to a previously reported method (Chaves, Da Costa, 2008).

\section{Solvents, reagents and pharmaceutical excipients}

Solvents for HPLC analysis (HPLC grade) were supplied by Mallinckrodt Baker (USA); solvents for UV analysis, reagents and salts were supplied by Merck (Rio de Janeiro, Brazil). The water was purified using a Milli-Q system (Millipore ${ }^{\circledR}$, USA). Phosphate buffer $\mathrm{pH} 7.5$ and $\mathrm{HCl}$ buffer $\mathrm{pH} 1.2$ were prepared according to the United States Pharmacopoeia (1995) specifications. The pharmaceutical ingredients, colloidal silicon dioxide (Aerosil $200^{\circledR}$ ), lactose monohydrate (lactose), microcrystalline cellulose (PH 102), magnesium stearate, sodium starch glicolate, polyvinylpyrrolidone (PVP) K30, and talc were supplied by Henrifarma (Brazil). Eudragit L 30 D $55^{\circledR}$ (Rohm, Germany) and triethyl citrate were supplied by Almapal (Brazil). Simethicone (Dow Corning ${ }^{\circledR}$, Belgium), titanium dioxide and polysorbate 80 were supplied by Gerbras (São Paulo, Brazil). 


\section{Plant material}

Powdered aerial parts of $T$. parthenium were purchased from Galilee Herbal Remedies (Kibbutz Kfar Hanassi, Israel) and submitted to several analyses in order to certificate its authenticity (Chaves, Da Costa, 2008).

\section{Preparation of feverfew hydroalcoholic extract}

The hydroalcoholic extract was obtained by percolation of the T.parthenium powder in $70 \%$ ethanol according to the German Pharmacopoeia specifications, described by List and Schmidt (1989). Two parts of the extract were obtained from one part of the powder. This process was performed in three steps: 1 ) pre-swelling for $2 \mathrm{~h}$ with a $1: 3$ solvent to powder proportion; 2) intermediate maceration (24 h); 3) percolation (4-6 drops/min) per $100 \mathrm{~g}$ of powder (List, Schmidt, 1989).

\section{Spray drying of extracts}

The T. parthenium spray-dried powder was prepared from a suspension containing $55 \%$ of hydroalcoholic extract (w/w), $40 \%$ of water $(\mathrm{w} / \mathrm{w})$ and $5 \%$ of colloidal silicon dioxide. During the atomization procedure, the mixture was mixed with a magnetic stirring bar. The suspension was dried using a mini spray-drier model LM MSD 1.0 (Labmaq do Brasil Ltda., Brazil) with capacity of drying up to 1.0 litre per hour. The atomization was carried out with a two-fluid $1.2 \mathrm{~mm}$ pneumatic nozzle, and the dryer was operated in concurrent flow. A summary of operational conditions employed during spray-drying is shown in Table I.

TABLE I - Summary of operational conditions during spray drying of extracts

\begin{tabular}{lc}
\hline Operational factor & Value \\
\hline Air flow rate, $\mathrm{m}^{3} / \mathrm{min}$ & 0.60 \\
Air inlet temperature, ${ }^{\circ} \mathrm{C}$ & 100 \\
Air outlet temperature, ${ }^{\circ} \mathrm{C}$ & 60 \\
Extract feed rate, $\mathrm{mL} / \mathrm{min}$ & 1.5 \\
Nozzle air pressure, $\mathrm{kgf} / \mathrm{cm}^{2}$ & 4.0 \\
Nozzle air flow, $\mathrm{L} / \mathrm{min}$ & 40 \\
\hline
\end{tabular}

\section{Tablet compaction and coating}

Tablets were obtained by a direct compression method in an eccentric compression machine (Fabbe ${ }^{\circledR}$, Brazil) using an $8 \mathrm{~mm}$ bi-concave punction regulated to obtain tablets of $200 \mathrm{mg}$. Excipients (Table II) were sieved and mixed in a geometric order. The spray-dried extract was mixed with sodium starch glicolate, cellulose and lactose. The magnesium stearate was mixed with talc and colloidal silicon dioxide, followed by PVP. Finally, the components were mixed thoroughly.

The tablets were coated in a lab scale Wurster bed coater model SBC 1.0 (Labmaq do Brasil Ltda., Brazil) with capacity of up to $1.0 \mathrm{~kg}$ of tablets. The equipment is a bottom spray fluid bed coater. The coating suspension (Table III) was applied in a proportion of $4: 1(\mathrm{w} / \mathrm{v})$ tablets:suspension. The coating operational conditions are summarized in Table IV. The suspension components were mixed in a high shear mixer at 13,500 rpm during 5 min. Then, Eudragit ${ }^{\circledR}$ L30 D55 was added and the mixture was stirred with a magnetic bar at $50 \mathrm{rpm}$ for $1 \mathrm{~h}$ (Kfuri, Freitas, 2006).

TABLE II - Composition of tablets containing feverfew spraydried extract

\begin{tabular}{lc}
\hline Components & $\%$ \\
\hline Polyvinylpyrrolidone (PVP) K30 $^{\circledR}$ & 5 \\
Aerosil $^{\circledR}$ & 1 \\
Microcrystalline cellulose PH 102 & 44.03 \\
Sodium starch glicolate & 3 \\
Magnesium stearate & 2 \\
Lactose & 14.68 \\
Talc & 3 \\
T. parthenium spray-dried extract & 27.29 \\
\hline
\end{tabular}

TABLE III - Composition of coating suspension for the feverfew tablets

\begin{tabular}{ll}
\hline Formulation & $\%$ \\
\hline Eudragit L30 D55 & 15.0 \\
Simethicone & 0.5 \\
Polissorbate 80 & 0.6 \\
Talc & 3 \\
Titanium dioxide & 1.5 \\
Triethylcitrate & 2.1 \\
Water & 100.0 q.s. ad. \\
\hline
\end{tabular}

\section{Quantitative analysis of parthenolide}

The parthenolide content was determined by HPLC according to a previously reported method (Chaves, Da Costa, 2008). In summary, the stock solution of partheno- 
TABLE IV - Operational conditions for fluid bed coating of feverfew tablets.

\begin{tabular}{lc}
\hline Factors & \\
\hline Tablet, $\mathrm{mg}$ & 200 \\
Coating preparation & see Table III \\
Coating suspension feed rate, $\mathrm{mL} / \mathrm{min}$ & 1.5 \\
Spray nozzle air rate, $\mathrm{L} / \mathrm{min}$ & 50 \\
Spray nozzle air pressure, $\mathrm{kgf} / \mathrm{cm}^{2}$ & 2 \\
Fluidizing air temperature, ${ }^{\circ} \mathrm{C}$ & 45 \\
Fluidizing air flow rate, $\mathrm{m}^{3} / \mathrm{min}$ & 0.26 \\
\hline
\end{tabular}

lide was prepared dissolving $5 \mathrm{mg}$ of parthenolide in $5 \mathrm{~mL}$ of acetonitrile $\left(\mathrm{CH}_{3} \mathrm{CN}\right)$. Standard solutions with concentrations of $1,2,10,50,100,250,500$, and $750 \mu \mathrm{g} \mathrm{mL}$ were prepared from the parthenolide stock solution $(1 \mathrm{mg} / \mathrm{mL})$ by means of sequential dilution with $\mathrm{CH}_{3} \mathrm{CN} .150 \mathrm{mg}$ of the $T$. parthenium spray dried powder were extracted with $10 \mathrm{~mL}$ of $\mathrm{CH}_{3} \mathrm{CN}: \mathrm{H}_{2} \mathrm{O} 9: 1(\mathrm{v} / \mathrm{v})$, sonicated for $30 \mathrm{~min}$ and centrifuged for $12 \mathrm{~min}$. The supernatant was passed through a $0.45 \mu$ m nylon membrane (Sartorius, Spain). The injection sample volume was always $20 \mu \mathrm{L}$. The analyses were performed in triplicate and the parthenolide content was calculated on the basis of the peak area against a calibration curve prepared by injecting standard solutions (Chaves, Da Costa, 2008).

\section{Detection of santin in spray-dried extract}

The santin content was determined by HPLC according to a previously reported method (Chaves, Da Costa, 2008). A clean-up step with a C-18 Sep-Pak cartridge (Waters Association, Milford, USA) was used to remove interfering material of the T. parthenium spray dried powder. The cartridge was preconditioned with $5 \mathrm{~mL}$ of methanol and $5 \mathrm{~mL}$ of water. An aliquot of the extract $(1 \mathrm{~g})$ was mixed with $2 \mathrm{~mL}$ of ethanol and eluted with $10 \mathrm{~mL}$ of methanol $60 \%$. The solvent was evaporated and the residue was suspended in $1 \mathrm{~mL}$ of methanol $60 \%$. Santin was suspended in $1 \mathrm{~mL}$ of methanol $60 \%(1 \mathrm{mg} / \mathrm{mL})$. The samples were filtered through a $0.45 \mu$ m nylon membrane and directly injected into the HPLC system. Injection volume was $50 \mu \mathrm{L}$.

\section{Total flavonoid content of spray-dried extract}

The determination of total flavonoid content was carried out using a UV spectrophotometer model Kayak XA (Hewlett Packard, USA), according to the method described in the German Pharmacopoeia (De Paula, 1996).
Analyses with samples of $0.4 \mathrm{~g}$ were performed in triplicate. The following formula was used to calculate the total flavonoid content:

$\mathrm{TF}=\mathrm{A} \cdot \mathbf{f d} / \mathbf{5 0 0} \cdot \mathbf{p} \cdot \mathbf{( 1 0 0 - t )}$, where:

$\mathrm{TF}=$ total flavonoids calculated using quercetin as reference $(\% ; \mathrm{w} / \mathrm{w})$

$\mathrm{A}=$ absorbance

$\mathrm{p}=$ weight $(\mathrm{g})$

$\mathrm{t}=$ loss on drying $(0.41 \%)$

$\mathrm{fd}=$ dilution factor $(62500)$

\section{Particle size measurements}

The determination of particle size of the spraydried powder was performed using an optical microscope (Olympus BX 60) coupled with an image capture system (Sony CCD-Iris, Japan). The powder was homogeneously dispersed on a slate using a vacuum device (vacuumgage PD-10, Galai). The average particle diameter was calculated using the software Image Pro-Plus ${ }^{\circledR}$ (Media Cybernetics Inc. All ${ }^{\circledR}$, USA). The analyses were performed in triplicate, counting 270 to 300 particles in each measurement.

\section{Angle of repose}

The powder sample was put carefully in a funnel with bottom stem of $4.5 \mathrm{~mm}$ internal diameter. The powder was allowed to flow freely and the diameter and height of the mound formed were measured (Swarosky, 1987). The analyses were performed in triplicate and the angle of repose was calculated by the arc tangent of the ratio of mound height to radius.

\section{Tapped density}

The powder $(2.5 \mathrm{~g})$ was carefully placed into a $25 \mathrm{~mL}$ graduated cylinder. The cylinder was tapped 200 times and the powder volume was measured at every 20 taps. This procedure was repeated three times (Kawashima et al., 1988).

\section{Hygroscopicity evaluation}

Spray-dried powder moisture uptake was determined using a method modified from the one described by Senna et al. (1997). Powder samples (300 mg) were conditioned at $25^{\circ} \mathrm{C} \pm 1{ }^{\circ} \mathrm{C}$ in four airtight glass flasks with different saturated salt solutions in water (magnesium chloride hexahydrate, potassium carbonate, sodium nitrate 
and zinc sulphate), corresponding to $33,43.2,64.5$ and $90 \%$ relative humidity, respectively. The sample moisture content was gravimetrically determined at $24 \mathrm{~h}$ intervals during a 10-day period. These experiments were carried out in duplicate.

\section{Scanning electronic microscopy (SEM)}

The morphology of the spray-dried powders was evaluated by scanning electron microscopy (Field Emission Gun Philips $3000^{\circledR}$ ) at magnifications of 500, 1,000, 2,000 and 10,000x. Before the SEM, the samples were coated with gold/palladium under argon atmosphere using a Balzers evaporator (SCD 050, Bal-Tec, AU).

\section{Moisture content}

The residual moisture content of the spray-dried extracts was determined by weight loss in an oven at $105^{\circ} \mathrm{C}$ for $5 \mathrm{~h}$ using samples of $300 \mathrm{mg}$ (Farmacopéia Brasileira, 2000). Analyses were performed in triplicate.

\section{Parthenolide soluble content}

The parthenolide soluble fraction in the spray-dried powder was determined by dissolving it at 12 different concentrations $(20-100 \mathrm{mg} / \mathrm{mL})$ in phosphate $(\mathrm{pH} 7.5)$ and hydrogen chloride ( $\mathrm{pH} 1.2)$ buffers. Samples were stirred for $48 \mathrm{~h}$, at $37^{\circ} \mathrm{C}$ and $500 \mathrm{rpm}$ (Swarosky, 1987), filtered using $0.45 \mu \mathrm{m}$ membranes and then analyzed by HPLC (see Quantitative analysis of parthenolide).

\section{Evaluation of uncoated and coated tablets}

The average weight, hardness, friability and disintegration time of the uncoated and coated tablets were determined according to the methods described in the Brazilian Pharmacopoeia (1988). The hardness was determined using a Tablet Tester $8 \mathrm{M}$, the friability was measured with an Ética 300.1 friabilator and the disintegration time was measured in purified water at $37 \pm 0.5^{\circ} \mathrm{C}$, in an Ética 301 $\mathrm{AC}$ apparatus.

\section{Dissolution of coated tablets}

The coated and uncoated tablets containing $0.2 \%$ of parthenolide were inserted into dialysis bags which were subsequently immersed in flasks containing $10 \mathrm{~mL}$ of phosphate buffer $\mathrm{pH} 7.4$ under magnetic stirring at $100 \mathrm{rpm}$ and $37^{\circ} \mathrm{C}$. This procedure was adopted to guarantee that the dissolution test would be adequate for both sink conditions and the detectable range of parthenolide by the HPLC methodology adopted herein. Samples were collected at every $15 \mathrm{~min}$ for a $2 \mathrm{~h}$ period and then analyzed by HPLC (see Quantitative analysis of parthenolide).

\section{RESULTS AND DISCUSSION}

\section{Parthenolide quantification and flavonoids analyses}

The grinded herb contained $0.49 \%$ of parthenolide and $0.54 \%$ of total flavonoids. The hydroalcoholic extract presented total flavonoid and parthenolide and total solid contents of $1.05,1.06$ and $10.8 \%$, respectively. The total flavonoid and parthenolide contents in spray-dried extracts were $1.31 \%$ and $0.76 \%(\mathrm{w} / \mathrm{w})$, respectively, with relative standard deviations (RSD) of $6.9 \%$ and $1.6 \%$ (Table V). The low RSD obtained for triplicate quantifications demonstrate the adequacy of the methods.

According to literature, ethanol extracts should be prepared with ethanol and water and contain $70 \%$ or less of alcohol. In this work the alcohol 70 was chosen to prepare the extract by percolation because it showed the better extraction of parthenolide than other alcohol/water mixtures (data not shown).

TABLE V - Chemical, physical and physicochemical properties of feverfew spray-dried extract

\begin{tabular}{lccc}
\hline Assay & Result & RSD, \% & Literature data \\
\hline Total flavonoids content & 1.31 & 6.9 & - \\
Parthenolide content & 0.76 & 1.6 & $\begin{array}{c}0.1 \%-0.2 \%, \\
\text { Palevitch } \text { et al. } \\
\text { (1997) }\end{array}$ \\
Bulk density & 0.3846 & 0 & - \\
Moisture content & $\mathrm{g} / \mathrm{mL}$ & & - \\
Angle of repose & $0.41 \%$ & 8.5 & - \\
\hline
\end{tabular}

$* \mathrm{RSD}=$ relative standard deviation $=$ (standard deviation $/$ average) $\mathrm{x} 100$

The analysis of parthenolide from the spray-dried extract and solid dosage form are important to evaluate the overall process efficiency and reproducibility because this metabolite can undergo thermal or chemical degradation during the process. Furthermore, these metabolites are essential for the pharmacological effects of $T$. parthenium (Williams et al., 2003). The HPLC/DAD chromatograms obtained for parthenolide and spray-dried extract are shown in Figures 1A and 1B, respectively. The chromatogram 
in Figure 1B demonstrates the excellent resolution of the method for parthenolide, which was detected at $210 \mathrm{~nm}$ after a retention time of about $15 \mathrm{~min}$ (in the middle of the chromatogram).
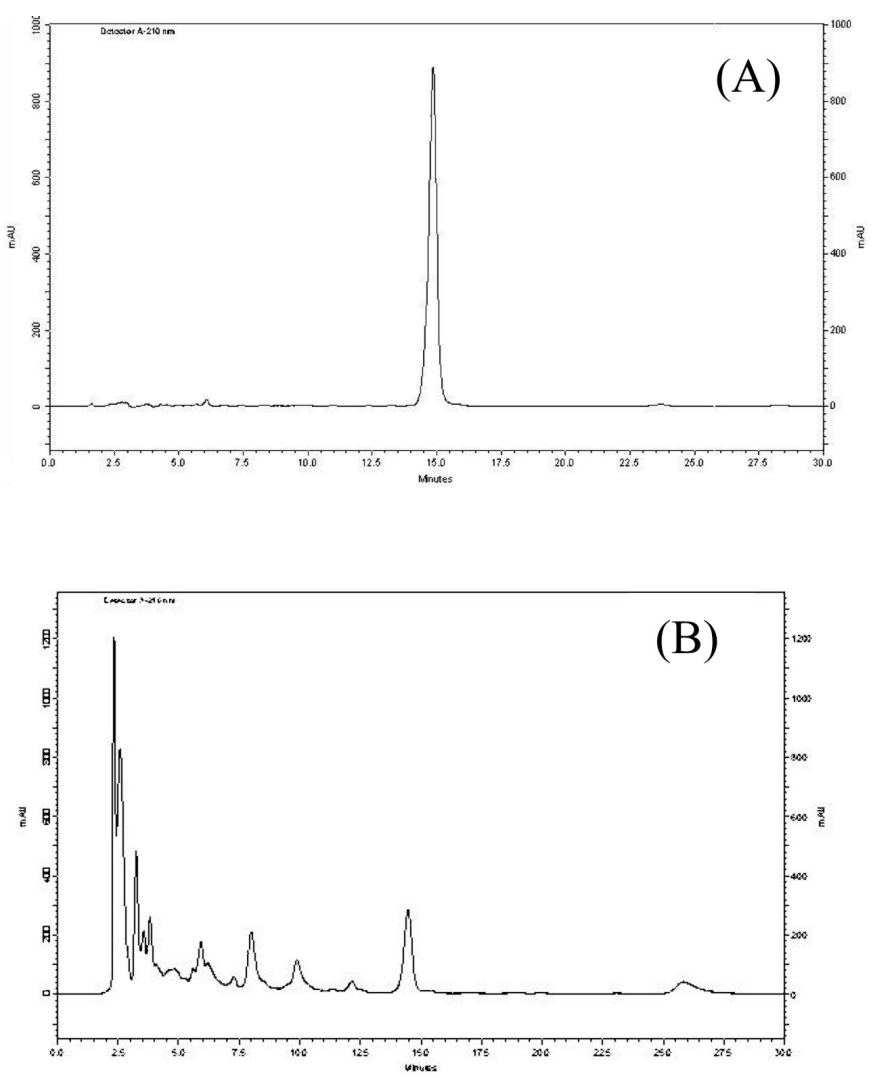

FIGURE 1 - HPLC/DAD chromatograms of parthenolide analyses, mAU x Time (min): (A) parthenolide standard; (B) spray-dried extract from feverfew. Mobile phase: acetonitrile: water (45:55). Flow-rate: $1 \mathrm{~mL} / \mathrm{min}$. Detection at $210 \mathrm{~nm}$.

The calibration curve was obtained for the peak area as a function of the standard concentration in the solution $(\mu \mathrm{g} / \mathrm{mL})$. The variation coefficients ranged from 0.23 to $3.7 \%$ (data not shown). Analyses of UV spectra collected at the beginning, in the middle and at the end of the parthenolide peak showed that the method presents specificity. The quantification limit was $0.07 \mu \mathrm{g}(70 \mu \mathrm{L}$ of a $1 \mu \mathrm{g} / \mathrm{mL}$ solution) and the detection limit, based on three times the noise level, was $0.02 \mu \mathrm{g}$ ( $20 \mu \mathrm{L}$ of a $1 \mu \mathrm{g} / \mathrm{mL}$ solution $)$. Acceptable intra and inter-assay precision were obtained for the method since the $\%$ RSD ranged from $0.34-4.1 \%$ for the intra-assays and $0.34-2.19 \%$ for the inter-assay precision tests (data not shown). The accuracy ranged from 94.09 - 99.99 (data not shown). These results demonstrate that the HPLC and sample extraction methods were reproducible.
Figures 2A and 2B present the HPLC/DAD chromatograms for flavonoid santin and the spray-dried extract, respectively. Santin was detected at $241 \mathrm{~nm}$ after a retention time of about 4 min, and Figure 2B shows that a good resolution was obtained under the applied conditions. Besides the analysis of santin, experiments were performed in order to determine the total flavonoid content by spectrophotometry using quercetin as reference.
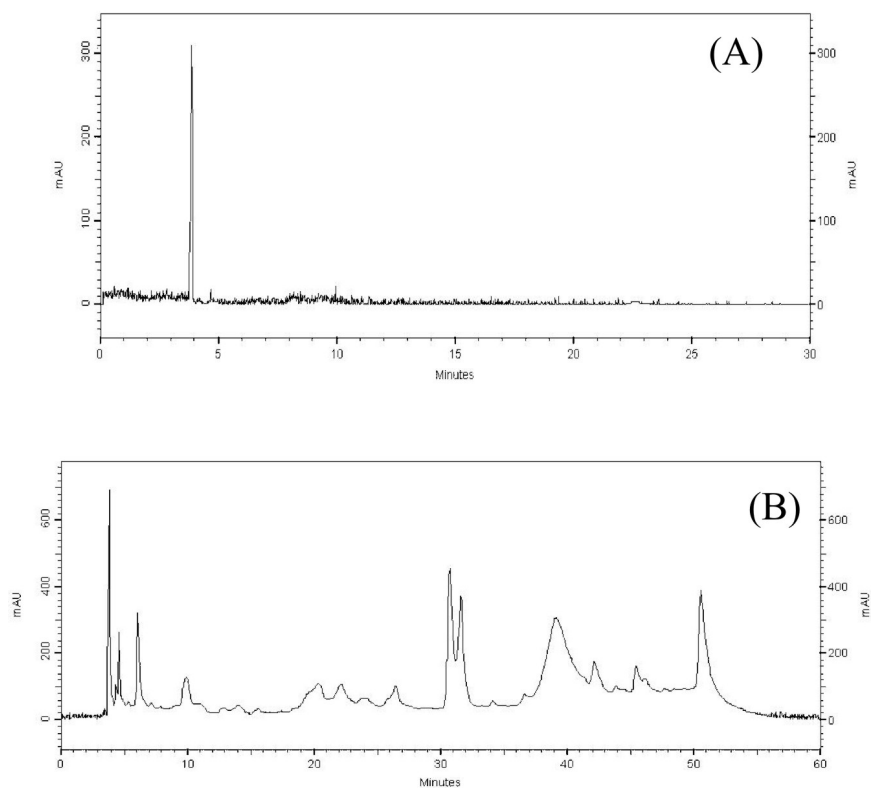

FIGURE 2 - HPLC/DAD chromatograms of santin, mAU x Time (min): (A) santin standard ; (B).spray-dried extract from feverfew. Mobile phase: solvent A ( $2 \%$ formic acid in water); solvent B (Acetonitrile). Gradient elution $0-10 \mathrm{~min} 15 \% \mathrm{~B}$ in A; $10-40 \min 15-30 \% \mathrm{~B}$ in $\mathrm{A}$ and $40-50 \min 30-15 \% \mathrm{~B}$ in $\mathrm{A}$. Flow-rate: $0.8 \mathrm{~mL} / \mathrm{min}$. Detection at $241 \mathrm{~nm}$.

Pharmacological investigations of feverfew and parthenolide have demonstrated that both present anti-inflammatory effect through the inhibition of eicosanoids as well as the transcription nuclear kappa-B (NF-kB) (Gruenwald et al., 2000; Garcia-Piñeres et al., 2001 ; 2004). Further studies revealed that flavonoids such as santin are also important anti-inflammatory constituents of this species (Long et al., 2003; Williams et al., 1999).

Although parthenolide as well as feverfew have been subject to several chemical and pharmacological investigations, a study describing the standardization of its dried including flavonoids analysis as well as parthenolide quantification was still lacking. 


\section{Characterization of the spray-dried extract}

Before spray drying, the liquid extracts were diluted in water to increase their fluidity and reduce the ethanol content, preventing explosion hazards and nozzle blocking during the atomization. The addition of colloidal silicon dioxide in the liquid extract reduces the adherence of the material to the equipment walls and improves the dry powder shape (spherical), size distribution and flowability (Runha et al., 2001).

Figure 3 presents the scanning electronic microscopy (SEM) of the spray-dried extract powder showing that the particles are spherical in shape, which is a common feature of the spray drying process. The particles sphericity is one of the advantages of spray-dried pharmaceutical powders, since this shape is associated with adequate flowability and bulk density. The results on particle size measurements (PSM) are shown in Figure 4, representing the cumulative size distribution. The PSM in Figure 4 showed that the powder sizes are homogenously distributed, and the cumulative size distribution fits to the Rosin-Rammler distribution with an acceptable squared correlation coefficient $\left(\mathrm{R}^{2}=0.9976\right)$. The average diameter based on $50 \%$ cumulative weight was $4 \mu \mathrm{m}$.
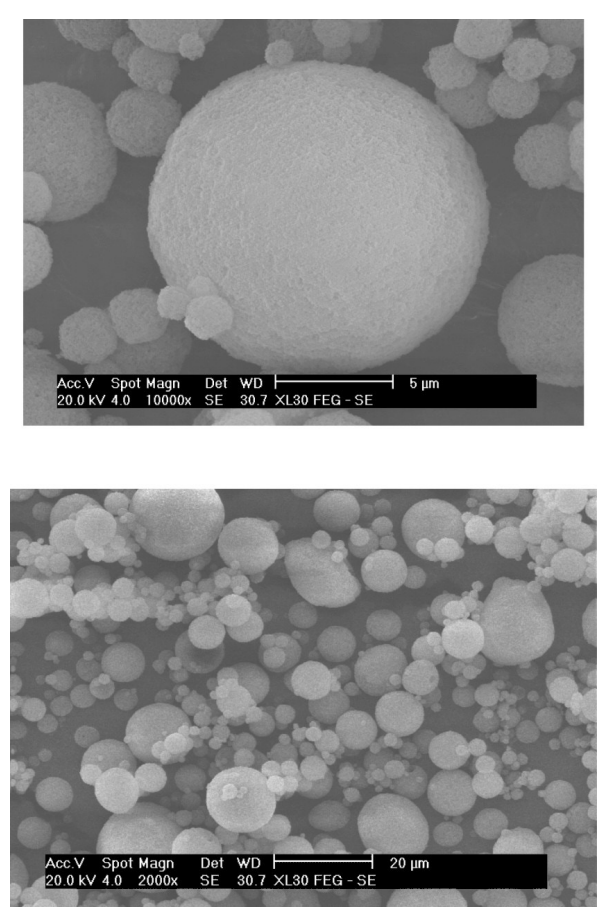

FIGURE 3 - SEM micrographs of feverfew spray-dried extract (x 10,000, 2,000).

Other important physicochemical properties of the spray-dried powder are presented in Table V. The "poured" angle of repose was $35.7^{\circ}$, which can be related to "intermediate" powder flow properties. Considering that this powder is obtained from a plant extract it is expected to have angle of repose higher than $30^{\circ}$ (Endale et al., 2002; Stariff et al., 2007; Von Eggelkraut et al., 2002).

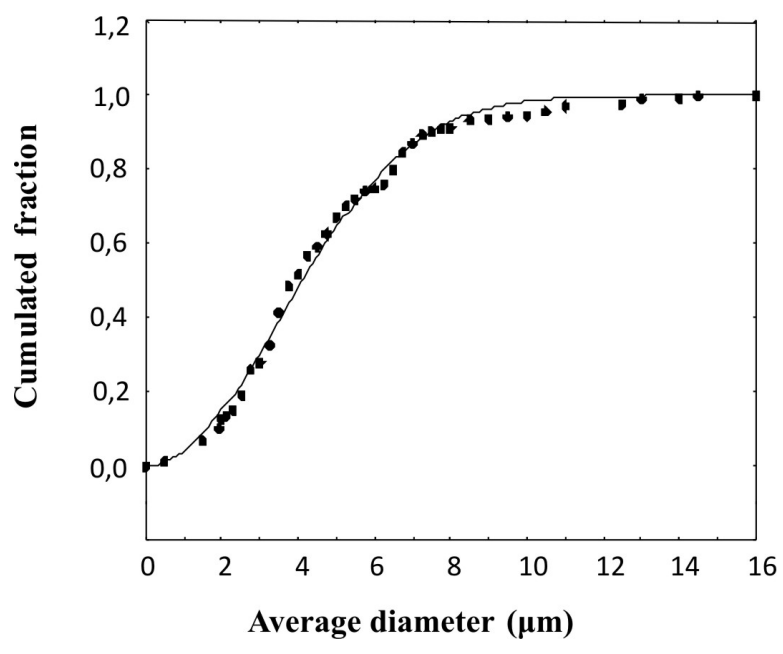

FIGURE 4 - Cumulative particle size distribution of spray-dried extract from feverfew, average diameter $(\mu \mathrm{m}) \mathrm{x}$ accumulated fraction ( $R R D$ model, $\left.\mathrm{R}^{2}=0,9976\right)$.

The dried extract presents low bulk density and moisture content, which are indicatives of good fluidity and chemical/microbiological stability, respectively. These properties are essential for the development of tablets (Senna et al., 1997).

Besides the determination of spray-dried extract moisture content, their hygroscopic properties were also determined by water uptake under different relative humidity conditions. The curves of water uptake or powder weight gain as function of time obtained for the relative humidity of 33, 43, 65 and 90\% are shown in Figure 5. As can be seen, except at the relative humidity of $90 \%$, the spray-dried extracts showed very low water adsorption during the entire experiment $(240 \mathrm{~h})$. This can be explained by the non-hygroscopic characteristic of the drying aid used (colloidal silicon dioxide). However, under extreme relative humidity conditions (90\%), the powder absorbs water in the initial $72 \mathrm{~h}$ and then the moisture content remains constant, attaining the balanced moisture content.

The solubility of parthenolide from the spray-dried extract was assayed in phosphate buffer solution $\mathrm{pH} 7.5$ at different powder concentrations, as presented in Figure 6. The graph demonstrates that there is a maximum in the percentage of parthenolide solubilised for the concentration of $50 \mathrm{mg} / \mathrm{mL}$ of spray-dried extract. However, in all concentrations only a fraction, 25 to $40 \%$, of parthenolide was solubilized. 


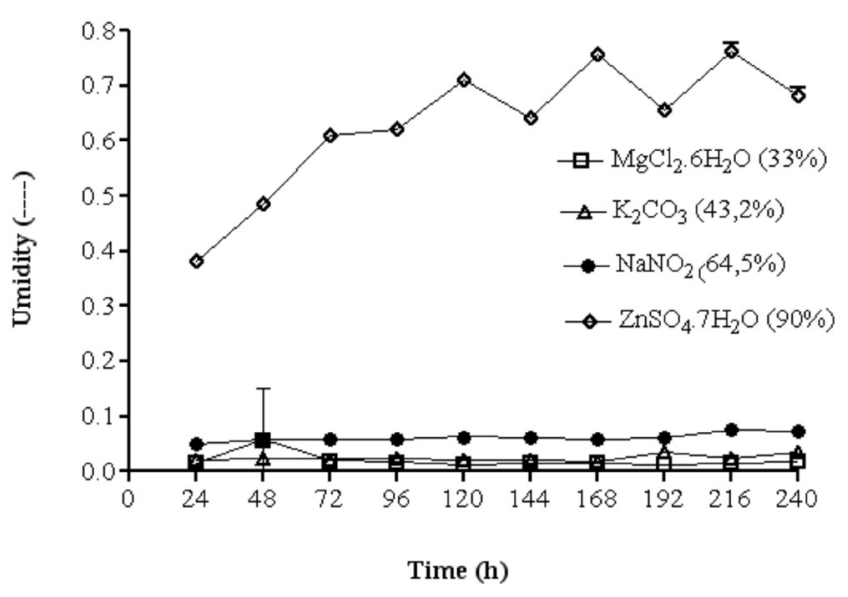

FIGURE 5 - Moisture uptake of the spray-dried extract from feverfew (humidity as a function of time).

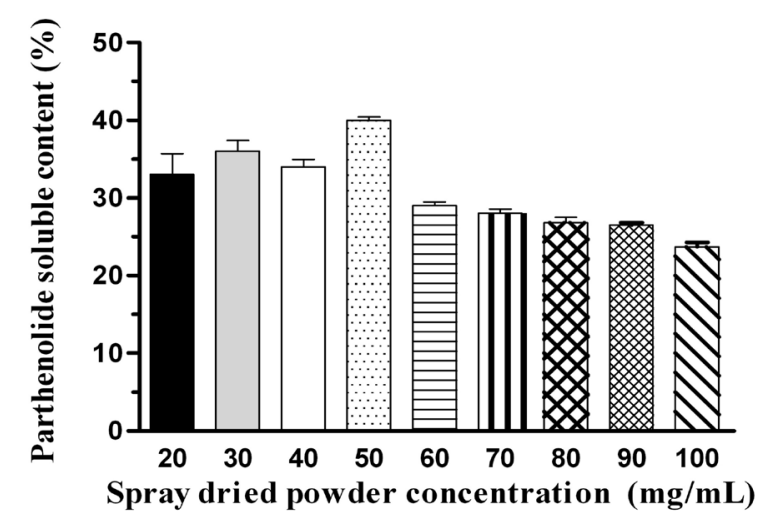

FIGURE 6 - Parthenolide soluble content in phosphate buffer $\mathrm{pH}$ 7.4 of feverfew spray-dried extract, spray powder concentration $(\mathrm{mg} / \mathrm{mL}) \times$ parthenolide content $(\%)$.

Experiments were also run to determine parthenolide solubility in $\mathrm{HCl}$ buffer $\mathrm{pH} 1.2$, but the amounts solubilized were not detectable by HPLC/DAD (data not shown). Based on these results, experiments were carried out to determine the dry extract $n$-octanol-water partition coefficient (log P). Nevertheless, it was not possible to determine this parameter since parthenolide was almost entirely found in the $n$-octanol phase. These results suggest that the feverfew pre-formulation may be absorbed through the intestinal mucosa. Previous work showed that parthenolide is effectively absorbed through the intestinal mucosa via a passive diffusion mechanism (Khan et al., 2003).

Recently, there has been an increasing interest in dry extracts of natural products. The dry extracts present obvious advantages in pharmaceutical formulations, such as the possibility of easy preparation of tablets and capsules and better conditions of stability. Moreover, we showed that the content of parthenolide and total flavonoids in the spray-dried extract of T. parthenium are higher than the powder of the plant (Chaves, Costa, in Press)

\section{Feverfew tablets}

The properties of the feverfew dry extract presented in the previous section demonstrated that it is fairly adequate for direct compression, although this is not the usual characteristic of dry herbal extracts (Palma et al., 2002). The direct compression method is faster and simple, but requires the use of excipients with good flow and compressibility properties, such as microcrystalline cellulose PH 102, PVP 30, magnesium stearate and colloidal silicon dioxide. The amount of spray-dried extract in tablets was established according to literature information of parthenolide therapeutical doses, ranging from 0.1 to $0.4 \mathrm{mg}$ daily (Gruenwall et al., 2000). The formulation in this work presents a total parthenolide content of $0.4 \mathrm{mg}$. The formulation used is shown in Table II, and during the whole compression process it showed none of the proble$\mathrm{ms}$ associated with unsatisfactory tableting.

Some important properties of the tablets obtained are presented in Table VI, demonstrating that the cores have adequate hardness, friability and weight uniformity. On the other hand, the tablets rapidly disintegrate in simulated gastric fluid (8 min).

The previous reports on gastrointestinal irritation, abdominal pain and heartburn of feverfew preparations (Johnson et al., 1985; Murphy et al., 1988; O'Hara et al., 1998 ) indicate that enteric coating of the solid dosage form to allow release only in the intestine would be more adequate. Aqueous polymeric dispersions have gained popularity and are replacing solvent-based systems due their lower toxicity level and environment friendly standpoint. Acrylate polymers and their derivates such Eudragit L30 D-55 in a form of aqueous dispersion are widely used in the pharmaceutical industry as coating materials (Zhang et al., 2007)

The spouted bed and its variants have been extensively studied for diverse unit operations such drying of granules and pastes and particle coating. In the pharmaceutical field, spouted bed coating has been used for tablets, capsules and granule coating with excellent results (Kfuri, Freitas, 2006) The recent development of the new aqueous polymeric emulsions for pharmaceutical coating has generated interest in alternative equipment, since the traditional pan coaters were shown to be ineffective in this case, due to their low aeration profiles and consequently low drying capacity. Fluidized and spouted beds have been the choice to overcome this limitation, due to their high level of aeration and good gas-solid contact. The previous 
studied published by our group (Kfuri, Freitas, 2006) showed that the fluidized bed conditions used here, presented good coating quality without problems of agglomeration, picking or any other factor related to poor drying conditions and that these operational conditions can be applied for the coating of tablets.

The properties of coated tablets can be seen in TABLE VI, showing an increase in hardness and decrease in friability, as expected for Eudragit ${ }^{\mathbb{R}}$ L30 D55 coated cores. The tablets weight variation also decreased, which is indicative of the good coating uniformity provided by the fluid bed process. The disintegration test showed that tablets do not disintegrate in $\mathrm{HCl}$ solution, and totally disintegrate after $19 \mathrm{~min}$ in phosphate buffer.

According to literature specifications, $70-75 \%$ of the drug should be released in 45-60 min (United States Pharmacopoeia, 1995). However, the release profile can be limited by the physicochemical properties of parthenolide, such as the low solubility, as well as by the tablet formulation. Due to the poor parthenolide solubility and to the limit of detection of the HPLC method used in this work, the dissolution test was performed with modifications, as detailed in the materials and methods section. The dissolution profile is presented in Figure 7.

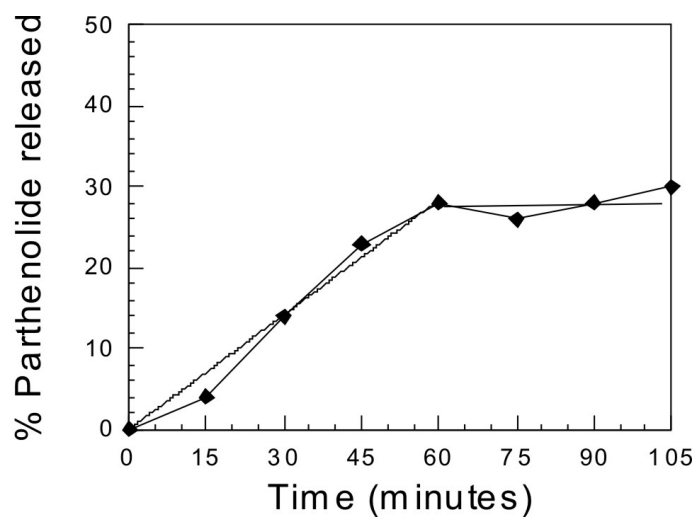

FIGURE 7 - Parthenolide dissolution from feverfew tablets in phosphate buffer $\mathrm{pH} 7.5$, parthenolide released (\%) x Time (min); each symbol represents the average of triplicates.
The dissolution profile demonstrates a linear rate until it reaches the maximum amount of parthenolide released in approximately $60 \mathrm{~min}$. The linear section of parthenolide release, or zero order models, fitted to the dissolution data with squared correlation coefficient of 0.9916 and is adequate for this formulation. The release rate was $0.47 \%$ per minute, which corresponds to $1.88 \mu \mathrm{g}$ of parthenolide per minute. However, due to the already mentioned poor solubility of the parthenolide, only a small fraction $(30 \%)$ of this compound was released during the tests, which corresponds to $0.12 \mathrm{mg}$ of parthenolide. The tablet formulation based on the feverfew spray-dried extract was demonstrated to be adequate for this phytomedicine.

\section{CONCLUSIONS}

The procedures described herein can be used to prepare and evaluate a pre-formulation of feverfew with essential properties for the development of a high-quality phytomedicine. The spray-dried extract demonstrated adequate properties, such as particle size and shape, bulk density, flowability, and compressibility. Furthermore, it was possible detect parthenolide and flavonoids after drying process. The characteristics of the tablets obtained confirmed the good compressibility of the spray-dried extract and showed adequate pharmacotechnical properties. However, the assays on parthenolide solubility showed that efforts should be directed towards the development of $T$. parthenium inclusions or complexes with solubility helpers.

\section{ACKNOWLEDGEMENTS}

The authors are grateful to FAPESP/Brazil (Contract/grant \#01 12638-2) for financial support. We thank Dr. Élida A. Stefanello (UFPR, Brazil) for providing parthenolide, Antonio M. L. Prieto (UFSCar, Brazil) for SEM analysis, Dr. Mônica L. Aguiar (UFSCar, Brazil) for PSM analysis, Giovanna Bonfante Borini (FCFRP-USP, Brazil) for suggestions and Dr. Paul Gates (University of Bristol, UK) for English revision.

TABLE VI - Pharmaceutics properties of feverfew tablets

\begin{tabular}{|c|c|c|c|c|c|c|}
\hline \multirow{2}{*}{\multicolumn{2}{|c|}{ Assay }} & \multicolumn{2}{|c|}{ Results } & \multicolumn{2}{|c|}{ RSD (\%) } & \multirow[t]{2}{*}{ Literature data } \\
\hline & & uncoated & coated & uncoated & coated & \\
\hline Hardness (kgf) & & 5.5 & 11.95 & 7.70 & 7.40 & $4.5 \mathrm{kgf}$ \\
\hline Friability (\%) & & 0.11 & 0.19 & - & - & $1.5 \%$ \\
\hline Weight (mg) & & 196.05 & 202.85 & 3.90 & 3.30 & $7.5 \%$ \\
\hline \multirow{2}{*}{ Disintegration (min) } & $\mathrm{pH} 1.2$ & 8,00 & $>120$ & - & - & \\
\hline & $\mathrm{pH} 7.4$ & - & 19,00 & - & - & \\
\hline
\end{tabular}




\section{REFERENCES}

ABOURASHED, E.A.; KHAN, I.A. Determination of parthenolide in selected feverfew products by liquid chromatography. J. AOAC Int., Gaithersburg, v.4, p.789$792,2000$.

BARNES, J. Quality, efficacy and safety of complementary medicines: fashions, facts and the future. Part I. Regulation and quality. Br. J. Clin. Pharmacol., Oxford, v.55, p.226233, 2003.

BOLHMANN, F.; ZDERO, C. Sesquiterpene lactones and other constituents from Tanacetum parthenium. Phytochemistry, Oxford, v.10, p.2543-2549, 1982.

CALIXTO, J.B. Efficacy, safety, quality control, marketing and regulatory guidelines for herbal medicines (phytotherapeutic agents). Braz. J. Med. Biol. Res., Ribeirão Preto, v.33, p.179-189, 2000.

CHAVES, J.S.; DA COSTA, F.B. A proposal for the quality control of Tanacetum parthenium (feverfew) and its hydroalcoholic extract. Rev. Bras. Farmacogn., João Pessoa, v.18, p.360-366, 2008.

DE PAULA, I.C. Desenvolvimento tecnológico de forma farmacêutica plástica contendo extrato seco nebulizado de Achyrocline satureoides (Lam.) DC. Compositae - marcela, Porto Alegre, 1996. 194p. [Dissertação de Mestrado: Faculdade de Ciências Farmacêuticas. UFRGS].

ENDALE, A.; SCHMIDT, P.C; GEBRE-MARIAM, T. Standardisation and physicochemical characterisation of the extracts of seeds of Glinus lotoides. Pharmazie, Eschborn, v.59, p.34-38, 2004.

FARMACOPÉIA BRASILEIRA. 4. ed. São Paulo: Editora Atheneu, 2000. $495 \mathrm{p}$.

FUKUDA, K.; HIBIYA, Y.; MUTOH, M.; OHNO, Y.; YAMASHITA, K.; AKAO, S.; FUJIWARA, H. Inhibition by parthenolide of phorbol ester-induced transcriptional activation of inducible nitric oxide synthase gene in a human monocyte cell line THP-1. Biochem. Pharmacol., Oxford, v.60, p.595-600, 2000.

GARCIA-PIÑERES, A.J.; CASTRO, V.; MORA, G.; SCHMIDT, T.J.; STRUNCK, E.; PAHL, H.L.; MERFORT, I. Cysteine 38 in p65/NF-kB plays a crucial role in DNA binding inhibition by sesquiterpene lactones. J. Biol. Chem., Maryland, v.276, p.39713-39720, 2001.
GARCIA-PIÑERES, A.J.; LINDENMEYER, M.T.; MERFORT, I. Role of cysteine residues of $\mathrm{p} 65 / \mathrm{NFKB}$ on the inhibition by the sesquiterpene lactone parthenolide and N-ethyl maleimide, and on its transactiving potential. Life Science, Amsterdam, v.75, p.841-856. 2004.

GRUENWALD, J.; BRENDLER, T.; JAENICKE, C. PDR for Herbal Medicines. 2 ed., Montvale, New Jersey: Medical Economics Company, 2000. p.306-309.

HWANG, D.; FISCHER, N.H.; JANG, B.C.; TAK, H.; KIM, J.K.; LEE, W. Inhibition of the expression of inducible cyclooxygenase and proinflammatory cytokines by sesquiterpene lactones in macrophages correlates with the inhibition of MAP kinases. Biochem. Biophys. Res. Commun., San Diego, v.226, p.810-818, 1996.

JOHNSON, E.S.; KADAM, N.P.; HYLANDS, D.M.; HYLANDS, P.J. Efficacy of feverfew as prophylactic treatment of migraine. Br. Med. J., London, v.291, p.64956569, 1985.

KAWASHIMA, Y.; TANKANORI, S.; HINO, T.; YAMAMOTO, H.; TAKEUCHI, H. Design of inhalation dry powder of pranlukast hydrate to improve dispersibility by the surface modification with light anhydrous silicic acid (Aerosil 200). Int. J. Pharm., Amsterdan, v.173, p.243-251, 1998.

KHAN, S.I.; ABOURASHED, E.A.; KHAN, I.A.; WALKER, L.A. Transport of parthenolide across human intestinal cells (Caco-2). Planta Med., Stutgartt, v.69, p.1009-1012, 2003.

KFURI, C.; FREITAS, L. A. P. A comparative study of spouted and spout fluid beds for Tablets coating. Dry. Technol., Philadelphia, v.23, p.2369-2388, 2006.

KWOK, B.H.B.; KOH, B.; NDUBUISI, M.I.; ELOFSSON, M.; CREWS, C.M. The anti-inflammatory natural product parthenolide from the medicinal herb feverfew directly binds to and inhibits IkB kinase. Chem. Biol., London, v.8, p.759-766, 2001.

LINDEN, R.; ORTEGA, G.G.; PETROVICK, P.R.; BASSANI, V.L. Response surface analysis applied to the preparation of tablets containing a high concentration of vegetable. Drug Develop. Ind. Pharm., Philadelphia, v.4, p.444-446, 2000.

LIST, P.H.; SCHMIDT, P.C. Medicinal Forms. In: Phytopharmaceutical Technology. Boston: Boca Raton, 1989. p. $1-20$ 
LONG, C.; SAULEAU, P.; DAVID, B.; LAVAUD, C.; CASSABOIS, V.; AUSSEIL, F.; MASSIOT, G. Bioactive flavonoids of Tanacetum parthenium revisited. Phytochemistry, Oxford, v.64, p.567-569, 2003.

MURPHY, J.J.; HEPTINSTALL, S.; MITCHELL, J.R.A. Randomized double-blind placebo-controlled trial of feverfew in migraine prevention. Lancet, London, v.2, p.189-192, 1988.

O'HARA, M.A.; KIEFER, D.; FARRELL, K.; KEMPER, K. A review of 12 commonly used medicinal herbs. Arch. Fam. Med., Chicago, v.7, p.523-536, 1998.

PALEVITCH, D.; EARON, G.; CARASSO, R. Feverfew (Tanacetum parthenium) as a prophylactic treatment for migraine: a double-blind placebo-controlled Study. PTR, Phytother. Res., West Sussex, v.11, p.508-511, 1997.

PALMA, S.; LUJÁN, C.; LLABOT, J.M.; BARBOZA, G.; MANZO, R.H.; ALLEMANDI, D.A. Design of Peumus boldus Tablets by direct compression using a novel dry plant extract. Int. J. Pharm., Amsterdam, v.233, p.191-198, 2002.

PEREIRA, C.A.M.; YARIWAKE, J.H.; LANÇAS, F.M.; WAUTERS, J.; TITS, M.; ANGENOT, L. A HPLC densitometric determination of flavonoids from Passiflora alata, P. edulis, P. incarnata and P. caerulea and comparison with HPLC method. Phytochem. Anal., West Sussex, v.15, p.241-248, 2004.

PFAFFENRATH, V.; DIENER, H.C.; FISCHER, M.; FRIEDE, M.; ZEPELIN, H.H.H. The efficacy and safety of Tanacetum parthenium (feverfew) in migraine prophylaxis - a doubleblind, multicentre, randomized placebo-controlled doseresponse study. Cephalalgia, Oxfordshire, v.22, p.523-532, 2002.

RUNHA, F.P.; CORDEIRO, D.S.; PEREIRA, C.A.M.; VILEGAS, J.; OLIVEIRA, W.P. Production of dry extracts of medicinal Brazilian plants by spouted bed process: Development of the process and evaluation of thermal degradation during the drying operation. Food Bioproducts Processing, Rugdby, v.79, p.1-9, 2001.

SILANO, M.; DE VICENZI, M.; DE VICENZI, A.; SILANO, $\mathrm{V}$. The new European legislation on traditional herbal medicines: main features and perspectives. Fitoterapia, Amsterdam, v.75, p.107-116, 2004.
SHARIFF, A.; MANNA, P. K.; PARANJOTHY, K. L. K.; MANJULA, M. Entrapment of andrographolide in crosslinked alginate pellets: II. Physicochemical characterization to study the pelletization of andrographolide. Pakistan J. Pharm. Sci., Karachi, v.2, p.9-15, 2007.

SWAROSK, Y.L. Powder testing guide methods of measuring the physical properties of bulk powders. New York: Elsevier Applied Science, 1987. 146 p.

SENNA, E.L.; PETROVICK, G.; ORTEGA, G.G. BASSANI, V.L. Preparation and characterization of spray-dried powders from Achyrocline satureoides (Lam.) DC extracts. PTR, Phytother. Res., West Sussex, v.11, p.123-127, 1997.

STEFANELLO, M.E.A.; ALVARENGA, M.A. Constituents of Talauma ovata Bark. Fitoterapia, Amsterdam, v.68, p.465-476, 1997.

UNITED STATES PHARMACOPOEIA. 23 ed. Rockville: United States Pharmacopoeia Convention, 1995. 2391p.

VOGLER, B.K.; PITTLER, M.H.; ERNST E. Feverfew as a preventive treatment for migraine: a systematic review. Cephalalgia, Oxfordshire, v.18, p.705-708, 1998.

VON EGGELKRAUT-GOTTANKA, S.G.; ABED, S.A.; MÜLLER, W.; SCHMIDT PC. Roller compaction and tabletting of St. John's wort plant dry extract using a gap width and force controlled roller compactor. I. Granulation and tabletting of eight different extract batches. Pharm. Dev. Technol., London, v.7, p. 433-445, 2002.

WEBER, J.T.; O'CONNOR, M.; HAYATAKA, K.; COLSON, N.; MEDORA, R.; RUSSO, E.B.; PARKER, K.K. Activity of parthenolide at $5 \mathrm{HT}_{2 \mathrm{~A}}$ receptors. J. Nat. Prod., Washington, v.60, p.651-653, 1997.

WILLIAMS, C.A.; HARBONE, J.B.; GEIGER, H.; HOULT, J.R.S. The flavonoids of Tanacetum parthenium and T. vulgare and their anti-inflammatory properties. Phytochemistry, Oxford, v.51, p.417-423, 1999.

YUNES, R.A.; PEDROSA, R.C.; CECHINEL FILHO,V. Fármacos e fitoterápicos: a necessidade do desenvolvimento da indústria de fitoterápicos e fitofármacos no Brasil. Quím. Nova, Campinas, v. 24, p.147-152, 2001. 
ZHANG, X. ; WANG, Y.; WANG, J, WANG, Y.; LI, S. Effect of pore former on the properties of casted film prepared from blends of Eudragit NE 30 D and Eudragit L 30 D-55. Chem. Pharm. Bull., Tokyo, v.55, p.1261-1263, 2007.
ZHOU, J.Z.; KOU, X.; STEVENSON D. Rapid extractions and high-performance liquid chromatographic determination of parthenolide in feverfew (Tanacetum parthenium). J. Agric. Food Chem., Washington, v.47, p.1018-1022, 1999.

Received for publication on $19^{\text {th }}$ December 2007 Accepted for publication on $29^{\text {th }}$ April 2009 